DOI 10.14746/ssp.2021.1.3

Ewa RADOMSKA

Uniwersytet Pedagogiczny im. Komisji Edukacji Narodowej w Krakowie

ORCID ID: 0000-0002-9503-534X

\title{
Poziom rozwoju gospodarki cyfrowej i społeczeństwa cyfrowego w Federacji Rosyjskiej - główne trendy i wyzwania
}

Streszczenie: Celem artykułu jest ocena poziomu rozwoju gospodarki cyfrowej i społeczeństwa cyfrowego w Federacji Rosyjskiej wraz z identyfikacją głównych trendów i wyzwań. Przeprowadzona analiza wykazała, iż poziom rozwoju gospodarki cyfrowej i społeczeństwa cyfrowego w Federacji Rosyjskiej kształtuje się na średnim poziomie w porównaniu do najbardziej konkurencyjnych na świecie gospodarek pod względem cyfryzacji. Mimo postępów w rozwoju gospodarki cyfrowej i społeczeństwa cyfrowego w FR w ramach programu cyfryzacji, wciąż występuje wiele obszarów wymagających poprawy i dalszych działań. Rządowy program cyfryzacji i ujęte w nim projekty mają znaczenie, ale pogorszenie koniunktury gospodarczej w FR wywołanej m.in. przez pandemię Covid-19 oraz wewnętrzne uwarunkowania systemowe nie sprzyjają ich wdrażaniu zgodnie z przyjętymi założeniami i ramami czasowymi (realizację wielu celów w ramach projektów ujętych w programie przesunięto do 2030 r.). Postępy w procesie cyfryzacji FR służące gospodarce i społeczeństwu dostrzegalne będą w perspektywie długookresowej.

Słowa kluczowe: gospodarka cyfrowa, społeczeństwo cyfrowe, technologia informacyjno-komunikacyjna, Federacja Rosyjska

\section{Wstęp}

Tedną z najbardziej dynamicznych zmian w zakresie stosunków społeczno-gospodarczych zachodzących we współczesnej gospodarce światowej jest rozwój technologii informacyjno-komunikacyjnych i związany z nim proces cyfryzacji gospodarki oraz społeczeństwa. Pojęcie cyfryzacji należy utożsamiać z adaptacją i wzrostem wykorzystywania technologii cyfrowych lub komputerowych przez organizacje, sektory gospodarki, kraje itd. (Peitz, Waldfogel, 2012). Gospodarka cyfrowa ${ }^{1}$ ro-

${ }^{1}$ Inne terminy określające ten nowy model gospodarki to: nowa gospodarka, e-gospodarka, gospodarka sieciowa, gospodarka oparta na wiedzy. 
zumiana jest jako szerokie spektrum działań gospodarczych, społecznych i kulturalnych wspieranych przez Internet i powiązane z nim technologie informacyjno-komunikacyjne (OECD, 2008), jako realizacja procesów gospodarczych z wykorzystaniem elektronicznych środków wymiany danych, a Internet jest niezbędnym narzędziem stanowiącym podstawową infrastrukturę rynku (Bukht, Heeks, 2017, s. 6-10). W gospodarce cyfrowej główne wartości mają charakter niematerialny, a korzystanie z nich traktowane jest jako źródło rozwoju (Andersen, 2015, s. 50). Z kolei, społeczeństwo cyfrowe ${ }^{2}$ to społeczeństwo, które korzysta $z$ dostępnych prywatnych i publicznych e-usług, czerpie z dóbr kultury i z rozrywki online, wykorzystuje dostępne materiały edukacyjne, komunikuje się z innymi, jest świadome korzyści i zagrożeń płynących z cyfryzacji w codziennym życiu, w działalności przedsiębiorstw, funkcjonowaniu sfery publicznej (Isin, Ruppert, 2015; Yates, Rice, 2020; Paralič, Sinčák, Hartono, Marik, 2020). Istotną rolę odgrywa zarówno dostęp do technologii informacyjno-komunikacyjnych, jak i umiejętności ich wykorzystania. Umiejętności cyfrowe to nie tylko umiejętności informatyczne (posługiwanie się komputerem i innymi urządzeniami elektronicznymi, korzystanie z Internetu, oprogramowania), ale także umiejętności informacyjne (wyszukiwanie informacji, rozumienie jej, selekcja i krytyczna ocena) i umiejętności funkcjonalne (realne wykorzystanie umiejętności informatycznych i informacyjnych w różnych sferach codziennego życia, takich jak finanse, praca i rozwój zawodowy, utrzymywanie relacji, zdrowie, hobby, zaangażowanie obywatelskie itd.) (Iordache, Mariën, Baelden, 2017, s. 6-30; Morandini, Thum-Thysen, Vandeplas, 2020, s. 3-4). Określenia „gospodarka cyfrowa” i ,społeczeństwo cyfrowe” są pewnymi skrótami myślowymi, próbami syntetycznego określenia wielowymiarowych, złożonych i dynamicznych w swojej naturze zmian w otoczeniu zewnętrznym związanych z rewolucją cyfrową, z której wynikają szanse, m.in. wzrost produktywności, zatrudnienia (Van Ark, 2018; Andrews, Nicoletti, Timiliotis, 2018), spadek kosztów transakcyjnych, kosztów pozyskiwania, przetwarzania i przechowywania produktów cyfrowych, nowe modele biznesowe itd. (Pieregud, 2016), jak i zagrożenia, m.in. bezrobocie technologiczne (Brynjolfsson, McAfee, 2011; Frey, Osborne, 2017; Bechichi, Grundke, Jamet, Squicciarini, 2018), wykluczenie cyfrowe (Ragnedda, 2017; Reisdorf, Rhinesmith, 2020), uzależnienie internetowe, postępująca anoni-

${ }^{2}$ Nazywane zamiennie: społeczeństwem postindustrialnym, informacyjnym, technologicznym, sieciowym, wirtualnym, wiedzy, opartym na wiedzy. 
mizacja kontaktów społecznych, obniżanie poczucia odpowiedzialności za przekazywane treści, łatwiejszy dostęp do treści szkodliwych (Meyer, 2018), ataki z użyciem szkodliwego oprogramowania, ataki socjotechniczne, m.in. wyłudzanie poufnych informacji przez podszywanie się pod godną zaufania osobę lub instytucję (Grzelak, Liedel, 2012; Schaub, 2018; Brooks, Craig, Short, 2018; Check Point Software Technologies, 2020). Aby sprostać tym zmianom, a równocześnie wykorzystać szanse i poradzić sobie z zagrożeniami, uczestnicy rynku - pojedyncze przedsiębiorstwa, jak i całe sektory, jednostka i społeczeństwo, administracja publiczna stoją przed wyzwaniem transformacji cyfrowej i adaptacji do niej. Chociaż rewolucja cyfrowa ma charakter globalny, tempo adaptacji i reakcji politycznych ma wymiar w dużej mierze krajowy lub regionalny, odzwierciedlając różne struktury gospodarcze i preferencje społeczne (Mühleisen, 2018, s. 7).

Celem artykułu jest ocena poziomu rozwoju gospodarki cyfrowej i społeczeństwa cyfrowego w Federacji Rosyjskiej wraz z identyfikacją głównych trendów i wyzwań. Kraj ten w ostatnich latach aktywnie angażuje się w proces cyfryzacji gospodarki. W IMD World Digital Competitiveness Ranking 2020 - Rosja zajęła 43 pozycję wśród najbardziej konkurencyjnych na świecie gospodarek pod względem cyfryzacji (adaptacja i wykorzystanie technologii cyfrowych w sferze publicznej i prywatnej) ${ }^{3}$ na 63 badanych krajów i oznacza spadek o 5 pozycji w stosunku do 2019 r. (IMD, 2020, s. 24). Potrzebę budowy gospodarki cyfrowej w Rosji zapisano w „Strategii rozwoju społeczeństwa informatycznego w FR na lata 2017-2030", zatwierdzonej dekretem prezydenckim z 9 maja 2017 r. (Administratsiya Prezidenta Rossii, 2017). Jego realizację stanowi rządowy program „Gospodarka cyfrowa Federacji Rosyjskiej” przyjęty 28 lipca 2017 r., w którym wskazano główne cele i kierunki cyfryzacji gospodarki (Pravitel'stvo Rossii, 2017, s. 2). W kolejnym dekrecie prezydenckim z 8 maja 2018 r., budowa gospodarki cyfrowej uznana została za jeden z 13 strategicznych projektów narodowych, których realizacja ma być głównym motorem rozwoju kraju do 2024 r. czyniąc gospodarkę rosyjską jedną z najbardziej konkurencyjnych na świecie (Administratsiya Prezidenta Rossii, 2018). W ramach programu cyfryzacji, na realizację sześciu równolegle wdrażanych projektów (Infrastruktura informatyczna, Nowoczesne technologie, Cyfrowa administracja publiczna, Kadry, Bez-

3 Dla porównania: 1 pozycja - Stany Zjednoczone, 2 - Singapur, 3 - Dania, 4 - Szwecja, 5 - Hongkong, 32 - Polska. 
pieczeństwo informatyczne, Regulacje prawne) przeznaczono do $2024 \mathrm{r}$. 1 634,9 mld rubli (ok. 22,3 mld USD) (Pravitel'stvo Rossii, 2019, s. 4). $\mathrm{Z}$ powodu pogorszenia koniunktury gospodarczej, w tym w wyniku kryzysu wywołanego przez pandemię Covid-19, ale również ze względu na problemy wewnętrzne o charakterze systemowym, realizację wielu celów określonych $\mathrm{w}$ strategicznych projektach narodowych przesunięto o 6 lat do 2030 r. (zgodnie z dekretem o narodowych celach Rosji do 2030 roku z 21 lipca 2020 r.) (Administratsiya Prezidenta Rossii, 2020).

Ze względu na brak ogólnie przyjętej definicji ,gospodarki cyfrowej”, „sektora cyfrowego", „społeczeństwa cyfrowego”, występują problemy z pomiarem gospodarki cyfrowej i społeczeństwa cyfrowego (Dimelis, Papaioannou, 2010; Manyika, Roxburgh, 2011; Vu, 2011; Sassi, Goaied, 2013; Graham, 2014; IMF, 2018). Do identyfikacji i oceny poziomu rozwoju gospodarki cyfrowej oraz społeczeństwa cyfrowego Federacji Rosyjskiej wykorzystano elementy składowe Indeksu Gospodarki Cyfrowej i Społeczeństwa Cyfrowego (The Digital Economy and Society Index - DESI) stosowanego przez Komisję Europejską (KE) do oceny postępów krajów UE w rozwoju gospodarki cyfrowej i społeczeństwa cyfrowego. Obejmują one: 1) łączność (ang. connectivity), 2) kapitał ludzki (ang. human capital), 3) wykorzystanie internetu (ang. use of internet service), 4) integracja technologii cyfrowych (ang. integration of digital technology) oraz 5) cyfrowe usługi publiczne (ang. digital public services). Uwzględniając ograniczenia metodologii KE oraz bariery w dostępie do pełnych i rzetelnych danych, analiza ww. obszarów stanowi próbę spojrzenia na postępy Federacji Rosyjskiej w rozwoju gospodarki cyfrowej i społeczeństwa cyfrowego z różnych punktów widzenia, identyfikacji głównych trendów, obszarów, które wymagają dalszych działań.

\section{Lączność: stałe sieci szerokopasmowe, mobilne usługi szerokopasmowe, prędkość i ceny lączy szerokopasmowych}

Od 2015 r. Internet w Rosji jest dostępny dla przedsiębiorstw i użytkowników domowych w różnych formach, w tym dial-up, kablowe, DSL, FTTH, komórkowe, bezprzewodowe i satelitarne. Rosja osiągnęła znaczący postęp w zapewnianiu swoim obywatelom łączności szerokopasmowej. Mobilna łączność szerokopasmowa jest bliska średniej dla gospodarek rozwiniętych (60 aktywnych abonamentów na 100 mieszkańców), wskaźniki penetracji telefonii komórkowej należą do jednych 
z najwyższych na świecie, a Rosja jest światowym liderem pod względem stałego dostępu szerokopasmowego dla ponad 90 proc. rosyjskich gospodarstw domowych. Średnia prędkość łącza internetowego w Rosji, wynosząca 7,4 Mbit/s, jest również prawie dwukrotnie większa niż średnia światowa wynosząca 3,8 Mbit/s. Według stanu na wrzesień $2020 \mathrm{r}$. Rosja zajmowała 47. miejsce wśród krajów świata pod względem szybkości stacjonarnego szerokopasmowego dostępu do Internetu, ze średnią prędkością pobierania 75,91 Mbit/s, i 88. pod względem szybkości dostępu do Internetu w sieci komórkowej z 22,83 Mbit/s. Konkurujący ze sobą dostawcy Internetu (Rostelecom, ER-Telecom, VimpelCom, MTS, Trans Telekom i in.) walczą o klientów cenami, stąd opłaty nie są wysokie. Analitycy serwisu rabatowego Picodi.com w grudniu 2019 r. porównali ceny 233 największych dostawców nielimitowanego domowego Internetu światłowodowego w 62 krajach świata. Spośród badanych krajów najwięcej za Internet o prędkości $100 \mathrm{Mbps/s} \mathrm{płacą} \mathrm{mieszkańcy}$ RPA - średnio 87 dol. miesięcznie. W Rosji, koszt wykupu miesięcznego dostępu do Internetu (o prędkości $100 \mathrm{Mbps}$ ) jest ponad jedenastokrotnie niższy niż w RPA i wynosi 7,68 dol. (Yarova, 2019). Powyższe dane nie uwzględniają istniejących dysproporcji regionalnych, biorąc pod uwagę ogromne rozmiary Rosji (ponad $17 \mathrm{mln} \mathrm{km}^{2}$ powierzchni) i zróżnicowany poziom rozwoju. FR stoi przed wyzwaniami związanymi z przepaścią cyfrową w docieraniu do obszarów wiejskich i oddalonych (Dyatlov, Selischeva, 2014; Rykov, Nagornyy, Koltsova, 2017; Chernova, Zobov, Starostin, 2019). Penetracja stałego łącza szerokopasmowego jest najwyższa w Moskwie, a najniższa w Czeczenii. Szansą nad zapewnieniem dostępu do Internetu $\mathrm{w}$ najbardziej odległych lokalizacjach geograficznych jest podjęty w 2019 r. wspólny rosyjsko-chiński projekt konstelacji satelitów niskoorbitalnych dla celów dostarczania superszybkiego Internetu, z czym wiąże się rozmieszczenie stacji naziemnych, które będą działać w powiązaniu z systemami nawigacji satelitarnej obu państw: rosyjskim Glonass i chińskim Baidu (Brokeš, 2019). Jak wykazały badania A. Gladkovej i M. Ragnedda (2020), najwyższy poziom cyfryzacji występuje w okręgach centralnych i północno-zachodnich FR. Na cyfryzację okręgów federalnych Rosji wpływa ich poziom rozwoju społeczno-gospodarczego, a także szereg obiektywnych czynników (odległość/izolacja, poziom urbanizacji, dostępność infrastruktury oraz koszty budowy nowej infrastruktury itp.). Nierówności cyfrowe w Rosji nadal istnieją i ich całkowite wyeliminowanie będzie wymagało więcej czasu, mimo że podejmowane są różne inicjatywy państwowe i społeczne. 


\section{Kapital ludzki: korzystanie z Internetu, podstawowe i zaawansowane umiejętności cyfrowe}

Na początku 2020 r. dostęp do Internetu miało w Rosji 118 mln osób, tj. 81 proc. populacji. Aktywnych członków sieci społecznościowych było $70 \mathrm{mln}, \mathrm{tj}$. 48 proc. populacji. Statystyczny internauta spędzał w sieci 7 godzin i 17 minut dziennie. W Rosji dynamicznie rośnie liczba użytkowników mobilnego Internetu. Na początku 2020 r. 87 proc. internautów (64 proc. rok wcześniej) łączyło się z siecią za pośrednictwem urządzeń mobilnych, głównie smartfonów (Kemp, 2020). W 2017 r. po raz pierwszy liczba osób korzystających z mobilnego Internetu była wyższa niż uzyskujących dostęp do sieci z komputerów stacjonarnych (RAEK, 2018). Dane te znacznie różnią się od szacunków Mediascope (do których odwołuje się Rosyjskie Stowarzyszenie Komunikacji Elektronicznej (RAEK) w raporcie z 2020 r.). Według nich, liczba użytkowników Runetu w lutym 2020 r. wynosiła 96,7 mln osób, tj. 79 proc. populacji (badanie dotyczyło osób powyżej 12. roku życia), co oznacza wzrost 4,2 proc. W porównaniu z 2019 r., przy czym ponad 86,2 mln użytkowników Internetu łączyło się z siecią za pośrednictwem urządzeń mobilnich, a 90 proc. wszystkich internautów korzystało z internetu codziennie (RAEK, 2020, s. 4). Pomimo szerokiego dostępu do Internetu, nadal jednak istnieją osoby wykluczone cyfrowo, choć zagadnienie inkluzji cyfrowej w Federacji Rosyjskiej nie jest wystarczająco zbadane. Zwracał na to uwagę Bank Światowy w raporcie z 2016 r., rekomendując wdrożenie Strategii Wykluczenia Społecznego, Digital Inclusion Strategy (World Bank, 2016, s. 34-35). Rozpowszechnienie się usług online sprawiło, że umiejętności cyfrowe stały się bardziej potrzebne niż kiedykolwiek wcześniej. Wyniki badań dotyczących umiejętności cyfrowych użytkowników Internetu w Rosji w porównaniu do wybranych krajów, przedstawiła Wyższa Szkoła Ekonomii (National Research University Higher School of Economics) w Moskwie w raporcie „Digital Economy. Pocked Data Book” z 2020 r. W analizowanym okresie 2015-2018 nie zwiększyły się znacznie umiejętności informatyczne Rosjan. Powyżej 40 proc. wszystkich osób w wielu 15-74 lata zadeklarowało umiejętność pracy z edytorem tekstu, powyżej 30 proc.: przesyłania plików przez e-mail, kopiowania lub przenoszenia plików, folderów, czy przesyłania plików między komputerem a innymi urządzeniami. Zaledwie 1 proc. użytkowników Internetu potrafi pisać oprogramowanie za pomocą języka oprogramowania, a poniżej 3 proc. zmienić ustawienia konfiguracji 
oprogramowania lub preferencji czy instalować lub ponownie instalować system operacyjny. Biorąc pod uwagę trzy wybrane umiejętności informatyczne - przesyłanie plików między komputerem a innymi urządzeniami (31 proc.), używanie arkuszy kalkulacyjnych (21 proc.), używanie oprogramowania do edycji zdjęć, filmów i plików audio (21 proc.), umiejętności osób w wieku 15-74 lata w Rosji kształtują się na najniższym poziomie w porównaniu do badanych krajów (Republika Czeska, Estonia, Finlandia, Francja, Niemcy, Szwecja, Wielka Brytania) (Gokhberg, Kislyakov, Kuzminov, Sabelnikova, 2020, s. 24-25). Badanie przeprowadzone przez VTsIOM i Social Business Group (SBG) w dniu 30 kwietnia 2020 r. pozwalają ocenić aktualny poziom umiejętności cyfrowych mieszkańców Federacji Rosyjskiej. Sondaż uwzględniał 17 kompetencji cyfrowych, których poziom w skali od 1 do 5 (gdzie 1 oznacza poziom najniższy, a 5 - poziom najwyższy) respondenci samodzielnie oceniali. Reprezentatywna próba w ramach projektu pilotażowego „VTsIOM-Satellite" obejmowała 1600 respondentów w wieku 18 lat lub starszych. Badanie wykazało, że najwyżej oceniane umiejętności to: wykonywanie zdjęć telefonem, wyszukiwanie informacji w Internecie, nagrywanie wideo telefonem, komunikowanie się lub wykonywanie połączeń za pośrednictwem różnych komunikatorów oraz za pomocą poczty elektronicznej. Z kolei, najniżej ocenione umiejętności to: możliwość instalacji i konfiguracji oprogramowania, edycji zdjęć i obrazów, przygotowania prezentacji oraz edycji materiału video. Średni wynik samooceny kompetencji cyfrowych pod względem wszystkich parametrów jest wyższy wśród zatrudnionych Rosjan w porównaniu ze średnią dla całej populacji. Większość respondentów (66 proc.) ocenia swój poziom kompetencji cyfrowych jako wystarczający, a 30 proc. jako niewystarczający (4 proc. miało trudności z odpowiedzią na to pytanie). Zadowolenie z poziomu kompetencji cyfrowych spada wraz z wiekiem (wynosi 82 proc. w grupie 18-24 lata i 48 proc. w grupie $60+$ ). 57 proc. respondentów z obszarów wiejskich zadeklarowało zadowolenie z poziomu swoich kompetencji cyfrowych (Davydov, 2020). Badanie VTsIOM/SBG dotyczy również przydatności kompetencji cyfrowych w warunkach pandemii Covid-19. 46 proc. respondentów w wieku 18 lat i więcej jest zatrudnionych. Wiosną 2020 r. 16 proc. przeniosło się do pracy w domu (9 proc. w pełnym wymiarze godzin i 7 proc. w niepełnym wymiarze godzin). 2 proc. ankietowanych pracowało zdalnie już przed pandemią. Organizacja pracy nie uległa zmianie w przypadku 27 proc. ankietowanych, którzy nadal wykonują swoje obowiązki na miejscu. Odsetek osób, które przeszły na 
pracę zdalną, jest najwyższy wśród specjalistów z wyższym wykształceniem w sektorze publicznym (60 proc.) i komercyjnym (51 proc.). W Moskwie i Sankt Petersburgu 29 proc. wszystkich dorosłych pracuje w domu. W miastach powyżej $1 \mathrm{mln}$ (bez dwóch wymienionych metropolii) jest to 21 proc., a na obszarach wiejskich tylko 10 proc. Większość respondentów negatywnie oceniło pracę w domu (61 proc w porównaniu z 36 proc., które oceniają ją pozytywnie). Zdaniem respondentów, ich kompetencje cyfrowe były wystarczające, aby dostosować się do zmieniających się warunków. W 81 proc. przypadków nie były im potrzebne nowe umiejętności, aby przejść na pracę zdalną, w domu. 19 proc. respondentów musiało podnieść swoje umiejętności związane głównie z korzystaniem z nowego oprogramowania (Davydov, 2020). W aspekcie kapitału ludzkiego warto zwrócić również uwagę na to, iż niewielki jest udział specjalistów w obszarze technologii informacyjno-komunikacyjnych w Federacji Rosyjskiej (2,5 proc. w ogólnym zatrudnieniu w 2018 r.) w porównaniu do innych krajów: Finlandii (6,9 proc.), Szwecji (5,9 proc.), Estonii (5,5 proc.), Wielkiej Brytanii (4,9 proc.). Większość z nich jest w wieku do 39 lat (67,8 proc.). W obszarze technologii cyfrowych i produkcji powiązanych z nimi dóbr i usług, największym zainteresowaniem na uczelniach wyższych cieszą się takie kierunki, jak: inżynieria komputerowa, elektronika i inżynieria komunikacji, inżynieria mechaniczna, inżynieria matematyki, bezpieczeństwo informacji, które również generują najwięcej absolwentów (Gokhberg, Kislyakov, Kuzminov, Sabelnikova, 2020, s. 78-79, 82), ale wciąż niewystarczająco wobec potrzeb gospodarki.

\section{Wykorzystanie Internetu: korzystanie przez obywateli z publikacji internetowych, komunikacja i przeprowadzanie transakcji przez Internet}

W odwołaniu do raportu „,Digital Economy. Pocked Data Book” Wyższej Szkoły Ekonomii w Moskwie, poniżej zaprezentowano wyniki badania wśród użytkowników Internetu w wieku od 15 do 74 lat w Federacji Rosyjskiej dotyczące działań internetowych związanych z komunikacją, dostępem do treści cyfrowych oraz szukaniem pracy lub wysyłaniem aplikacji o pracę, zamawianiem towarów lub usług, przeprowadzaniem transakcji finansowych. W obszarze komunikacji, użytkownicy Internetu w wieku 15-74 lata w Federacji Rosyjskiej są szczególnie aktywni w mediach społecznościowych (78 proc.). Udział osób nawiązujących 
połączenia telefoniczne lub video przez Internet (53 proc.) jest zbliżony do badanych krajów, natomiast bardzo niski jest udział użytkowników Internetu w Federacji Rosyjskiej dotyczący wysyłania/odbierania wiadomości e-mail (42 proc.). Według danych Centrum Lewady z Moskwy, w latach 2009-2019 z 94 do 72 proc. spadł odsetek Rosjan czerpiących informacje $z$ telewizji (ufa im ok. 55 proc. w porównaniu do 80 proc. przed dekadą), natomiast odsetek osób czerpiących informacje z Internetu i sieci społecznościowych wzrósł z 9 do ponad 30 proc. (zaufanie informacji z tych źródeł wzrosło kilkukrotnie i wyniosło w 2019 r. ok. 20 proc., przy czym występują różnice w zależności od grupy wiekowej). Z sieci społecznościowych, komunikatorów i blogów (najbardziej popularne w Rosji to Vkontakte, Instagram, Odnoklassniki, Facebook, YouTube) codziennie korzystało w 2019 r. 85 proc. użytkowników Internetu, głównie do 25. roku życia (Levada-Tsentr, 2019). W obszarze dostępu do treści cyfrowych, większy jest udział użytkowników Internetu w wieku 15-74 lata w Federacji Rosyjskiej odtwarzających lub pobierających filmy video lub gry komputerowe/mobilne (30 proc.), niż czytających lub pobierających gazety online/czasopisma/e-booki ( 23 proc.) - w tym przypadku jest to najniższy udział w porównaniu do badanych krajów, około 4-krotnie niższy niż w Republice Czeskiej (91 proc.), Estonii (90 proc.), Finlandii (90 proc.), Republice Korei (94 proc.). Pozostałe wyniki badania: 8 proc. podjęło działania związane z szukaniem pracy lub wysyłaniem aplikacji o pracę korzystając z Internetu, 35 proc. zamówiło towary lub usługi przez Internet, 39 proc. przeprowadziło transakcje finansowe przez Internet (Gokhberg, Kislyakov, Kuzminov, Sabelnikova, 2020, s. 29, 32, 33).

\section{Integracja technologii cyfrowych: cyfryzacja przedsiębiorstw i handel elektroniczny}

Rosyjski biznes odstaje od światowych liderów w sferze korzystania z technologii cyfrowych. Zgodnie z indeksem cyfryzacji biznesu (Business Digitalisation Index) Wyższej Szkoły Ekonomii w Moskwie (indeks ten określa tempo adaptacji przedsiębiorstw do cyfrowej transformacji w Rosji, krajach europejskich, Turcji, Korei Południowej i Japonii) Rosja zajęła w 2018 r. (ostatnie dostępne dane) 28 pozycję na 32 badane kraje $\mathrm{z}$ wynikiem kształtującym się na poziomie 31 (porównywalnie z Polską i Turcją) (Gokhberg, Kislyakov, Kuzminov, Sabelnikova, 2020, s. 42-43). Rosyjskie przedsiębiorstwa mogą się równać ze światowymi 
liderami (m.in. Finlandią, Republika Korei, Francją) jedynie pod względem dostępu do Internetu (90 proc.), w tym do szerokopasmowego Internetu (86 proc. wszystkich przedsiębiorstw). Znacznie natomiast odstają od nich w wielu obszarach: posiadania własnych stron internetowych, sprzedaży i zamawiania dóbr/usług online, korzystania z chmury obliczeniowej, z systemów RFID, ERP, CRM. Według danych za 2018 r.: 49 proc. przedsiębiorstw korzystających z Internetu posiadało własne strony internetowe, 15 proc. sprzedawało dobra/usługi online (było aktywnych w obszarze e-commerce), 20 proc. dokonywało zakupu dóbr/ usług online, 27 proc. korzystało z usług chmury obliczeniowej, 7 proc. korzystało z systemów identyfikacji osób i przedmiotów na odległość (RFID), 22 proc. korzystało z systemów planowania zasobów przedsiębiorstwa (ERP), 18 proc. korzystało z systemu CRM, który automatyzuje i wspomaga procesy na styku klient-organizacja w zakresie pozyskania oraz utrzymania klienta, czyli z systemu wspomagającego pracę działów marketingu, sprzedaży, obsługi klienta, a także zarządu (Gokhberg, Kislyakov, Kuzminov, Sabelnikova, 2020, s. 49-60). Według danych z lutego 2019 r., sytuacja nie zmieniała się istotnie, nadal występują różnice w ww. obszarach w porównaniu do najbardziej zaawansowanych krajów pod względem cyfryzacji przedsiębiorstw (Kevesh, Filatova, 2019, s. 2). Przedsiębiorstwa w Federacji Rosyjskiej korzystają z narzędzi bezpieczeństwa informacji, 79,2 proc. $\mathrm{z}$ automatycznej aktualizacji oprogramowania antywirusowego, 74,6 proc. $z$ elektronicznego podpisu cyfrowego, 60,9 proc. z firewalls/zapór (oprogramowania lub sprzętu), 55,9 proc. $\mathrm{z}$ filtrów antyspamowych, $47,1 \mathrm{z}$ szyfrowania danych w celu zapewnienia poufności, 42,6 proc. z systemu wykrywania włamań, ale występują znaczne różnice między branżami (najniższy poziom dbałości o bezpieczeństwo jest w branży nieruchomości) (Gokhberg, Kislyakov, Kuzminov, Sabelnikova, 2020, s. 61-62). Ocenia się, iż kryzys wywołany przez pandemię Covid-19 negatywnie wpłynie na rynek usług IT w perspektywie krótko i średniookresowej. Część przedsiębiorstw wstrzymało projekty modernizacji infrastruktury IT. Trudna sytuacja gospodarcza zniechęca do długoterminowych projektów integracji systemowej.

\section{Cyfrowe usługi publiczne: e-administracja}

Rządy na całym świecie stoją przed podwójnym wyzwaniem. Ich obywatele oczekują coraz wyższych standardów usług i chcą mieć możli- 
wość interakcji z rządem w Internecie równie łatwo, jak w przypadku banków i firm zajmujących się handlem internetowym. Jednocześnie rządy muszą obniżyć koszty administracyjne i zwiększyć skuteczność programów. Komisja Europejska definiuje e-administrację jako wykorzystywanie Internetu do dostarczania obywatelom informacji administracyjnych i świadczenia usług na ich rzecz (European Commission, 2013). W rankingu ONZ rozwoju usług e-administracji (E-Government Development Index - EGDI 2020) opublikowanym w 2020 r., Federacja Rosyjska zajęła 36 pozycję na 193 badane kraje, co oznacza bardzo wysoki wskaźnik EGDI: 0.8244. Indeks EGDI składa się z trzech komponentów obejmujących poziom rozwoju: usług online (Online Service Index) - wynik dla Rosji: 0.8176, infrastruktury telekomunikacyjnej (Telecommunications Infrastructure Index) - wynik dla Rosji: 0.7723 i kapitału ludzkiego (Human Capital Index) - wynik dla Rosji: 0.8833 (United Nations, 2020, s. 270). Według raportu Banku Światowego przygotowanym we współpracy z Institute of the Information Society „Digital Government 2020: Prospects for Russia", Rosja, mimo, że nie należy do czołówki najbardziej zaawansowanych na świecie państw pod względem wykorzystania technologii informacyjno-komunikacyjnych w administracji publicznej, w ostatnich latach poczyniła duże postępy w realizacji strategii e-administracji dotyczącej świadczenia usług cyfrowych. Większość mierzalnych wskaźników stosowanych w Rosji, podobnie jak w wielu innych krajach, dotyczy ocen poziomu e-Gotowości kraju (e-Readiness of the country), a także poszczególnych regionów czy branż. Według ekspertów Banku Światowego, wyzwaniem jest stworzenie nowego systemu monitorowania wykorzystania technologii informacyjno-komunikacyjnych w administracji publicznej w kontekście odpowiednich modeli dojrzałości cyfrowej rządu (Digital Government maturity models) (World Bank, 2016). Wyniki badania uwzględnione w raporcie „,Digital Economy. Pocked Data Book” Wyższej Szkoły Ekonomii w Moskwie wskazują, że w 2018 r. 95,3 proc. wszystkich organów władzy publicznej w Federacji Rosyjskiej miało dostęp do Internetu, w tym 89,9 proc. do Internetu szerokopasmowego, 55,5 proc. miało strony internetowe, a 25,7 proc. korzystało z chmury obliczeniowej. Nie występują pod tym względem większe różnice między organami władzy federalnej, regionalnej, lokalnej. W zakresie komunikacji Internet wykorzystywano głównie do interakcji przez e-mail (93,4 proc.), videokonferencji (44,4 proc.), rozmów telefonicznych przez Internet/VoIP (24 proc.), w zakresie źródeł informacji do korzystania z baz danych (34,3 proc.), płatnych subskrybcji elektronicznych 
baz danych i bibliotek (24,9 proc.). Internet wykorzystywany jest również do szkoleń pracowniczych (46,3 proc.), do rekrutacji pracowników (24,7 proc.) (Gokhberg, Kislyakov, Kuzminov, Sabelnikova, 2020, s. 64 65). Od 2017 r. spółka Rostelekom ${ }^{4}$ jest wyłącznym operatorem usług łączności obsługującym federalne organy państwa, odpowiada również za stworzenie zintegrowanej sieci łączności na potrzeby obronne, bezpieczeństwa i utrzymania porządku w państwie. Mniej niż połowa (42 proc.) osób fizycznych w Federacji Rosyjskiej podejmowała w 2018 r. interakcje internetowe z organami władzy publicznej pozyskując głównie informacje ze stron internetowych lub aplikacji (39 proc.), a w małym stopniu pobierając formularze urzędowe (16 proc.) i wysyłając uzupełnione formularze przez Internet (17 proc.). To mniej niż w Republice Czeskiej, Estonii, Finlandii, Francji, Niemczech, Szwecji, Wielkiej Brytanii, a na podobnym poziomie jak we Włoszech. Głównymi powodami powstrzymywania się od korzystania $\mathrm{z}$ usług publicznych $\mathrm{w}$ formie cyfrowej są: preferowanie osobistego stawiennictwa i bezpośrednich kontaktów (58,7 proc.), niewystarczające umiejętności lub wiedza (17,1 proc.), brak potrzeby (16,1 proc.), wymaganie osobistego stawiennictwa, aby złożyć oryginalne dokumenty pozwalające na skorzystanie z usługi $(12,1$ proc.). W przypadku sektora przedsiębiorstw sytuacja wygląda lepiej: około 69 proc. wszystkich przedsiębiorstw pobiera formularze urzędowe i wypełnione wysyła przez Internet, 60 proc. pozyskuje informacje ze stron internetowych lub aplikacji, ale tylko 26 proc. uczestniczy w elektronicznych zamówieniach publicznych (Gokhberg, Kislyakov, Kuzminov, Sabelnikova, 2020, s. 70-71). Państwowy Sbierbank, największy rosyjski bank, który rozwijał segment IT, przejmując udziały w prywatnych spół$\mathrm{kach}^{5}$ (Meshcheryakov, 2015), aktywny również w sektorze pozafinansowym. W listopadzie 2019 r. podjął współpracę z merostwem Moskwy dotyczącą obsługi mieszkańców stolicy w zakresie serwisów, np. systemu parkowania, opłaty za mieszkania i opłaty komunalne, rejestracji wizyt lekarskich, elektronicznych dzienniczków uczniowskich, z których chętnie korzystają (przeniesienia ich z oficjalnej strony merostwa Mos.ru na

${ }^{4}$ Posiada dominującą pozycję w sektorze łączności stacjonarnej i dostępu do stacjonarnego Internetu oraz jest jednym z czterech największych w Federacji Rosyjskiej operatorów sieci komórkowej, liderem na rynku usług IT, w tym przechowywania danych i dostępu do płatnej telewizji.

${ }^{5}$ W 2015 r. Skierbank przejął m.in. większościowy pakiet w spółkach Platius (serwis mobilnych płatności) oraz RuTarget (analiza zachowań konsumentów na podstawie big data). 
platformę Digital Platform Solutions umożliwiającą rozszerzenie usług skierowanych zarówno do mieszkańców, jak i przedsiębiorców, a także do urzędników) (Kuznetsova, Chernyshova, 2019).

Należy dodać, że od kilku lat władze rosyjskie starają się zwiększać kontrolę nad sektorem cyfrowym, preferując przedsiębiorstwa państwowe w realizacji projektów publicznych związanych z cyfryzacją FR. Uwarunkowania systemowe: ogólna niestabilność i niejednoznaczność przepisów prawnych, centralizacja i mała transparentność procesów decyzyjnych, korupcja, pierwszeństwo dla państwowych przedsiębiorstw powiązanych z elitami władzy (zwykle otrzymują kontrakty w sektorze ICT bez przetargów, na podstawie decyzji prezydenta lub premiera, realizują je często po zawyżonych cenach), mało korzystne warunki współpracy ustalane przez te przedsiębiorstwa dla podwykonawców, m.in. niskie stawki, opóźnienia w zapłatach lub ich niedokonywanie (Mereminskaya, Yastrebova, 2019), to główne czynniki niesprzyjające angażowaniu się sektora prywatnego w projekty publiczne.

\section{Podsumowanie}

W oparciu o przeprowadzoną analizę można sformułować następujące wnioski:

- Rozwój gospodarki cyfrowej i społeczeństwa cyfrowego jest elementem scentralizowanej, rządowej polityki ujętej w kluczowym programie „Gospodarka cyfrowa Federacji Rosyjskiej” (2017). Państwo nadaje tempo i kontroluje proces cyfryzacji we współpracy z największymi państwowymi przedsiębiorstwami, powiązanymi z elitami władzy. Występuje wiele barier wewnętrznych, systemowych zniechęcających przedsiębiorstwa prywatne do angażowania się w realizację projektów rządowych.

- Rosja osiągnęła znaczący postęp w zapewnieniu swoim obywatelom stałego dostępu do szerokopasmowego Internetu, stacjonarnego i mobilnego, po konkurencyjnych, stosunkowo niskich cenach, ale nie zajmuje wysokiej pozycji jeśli chodzi o szybkość dostępu do Internetu. Systematycznie rośnie ilość użytkowników Internetu mobilnego. Istniejące dysproporcje regionalne w poziomie cyfryzacji wymagają podjęcia bardziej aktywnych działań w dotarciu do obszarów wiejskich i oddalonych. Nierówności cyfrowe w FR dotyczą również stopnia penetracji Internetu, liczby użytkowników, wykorzystania 
e-usług, umiejętności cyfrowych. Szansą na poprawę w tym zakresie jest projekt „Infrastruktura informatyczna” w ramach rządowego programu cyfryzacji. Jego celem jest stworzenie globalnej i konkurencyjnej infrastruktury przesyłu, przetwarzania i magazynowania danych, przede wszystkim na bazie rodzimych technologii i oprogramowania, w tym: wdrożenie standardu 5G, technologii Internetu rzeczy, zapewnienie społeczeństwu dostępu do szerokopasmowego Internetu. $\mathrm{Na}$ jego realizację przeznaczono 772,4 mld rubli [ok. 10,5 mld dol.] (Pravitel'stvo Rossii, 2019, s. 4).

- Umiejętności cyfrowe użytkowników Internetu w Rosji oceniane są przez nich samych jako wystarczające, ale w porównaniu do innych krajów, ich poziom kształtuje się na niskim poziomie w odniesieniu do umiejętności informatycznych, informacyjnych i funkcjonalnych. Ograniczają się do podstawowych aktywności, np. wykonywanie zdjęć telefonem, wyszukiwanie informacji w Internecie, nagrywanie wideo telefonem, komunikowanie się lub wykonywanie połączeń za pośrednictwem różnych komunikatorów oraz za pomocą poczty elektronicznej. Użytkownicy Internetu są szczególnie aktywni w mediach społecznościowych, które oprócz innych portali internetowych są dla nich głównym źródłem informacji. W obszarze dostępu do treści cyfrowych, większy jest udział użytkowników Internetu odtwarzających lub pobierających filmy video lub gry komputerowe/mobilne, niż czytających lub pobierających gazety online, czasopisma, e-booki. Niski jest udział szukających pracy lub wysyłających aplikacje o pracę korzystając z Internetu, zamawiających towary lub usługi i przeprowadzających transakcje finansowe przez Internet. Aby rozwijać umiejętności i szerzej kompetencje cyfrowe, niezbędne jest wsparcie w obszarze edukacji, nauki, kształceniu przez całe życie, elastycznym dopasowaniu do indywidualnych potrzeb obywateli, wsparciu adresowanym do grup o zróżnicowanych poziomach kompetencji cyfrowych, ze szczególnym uwzględnieniem działań na rzecz włączenia cyfrowego. W rządowym programie cyfryzacji nie uwzględniono projektu odnoszącego się do ww. kwestii.

- Rosyjskie przedsiębiorstwa mogą się równać ze światowymi liderami pod względem dostępu do Internetu, w tym do szerokopasmowego, ale znacznie od nich odstają (zwłaszcza małe przedsiębiorstwa prywatne) w takich obszarach, jak np. posiadanie własnych stron internetowych, sprzedaż i zamawiania dóbr/usług online, korzystanie z chmury obliczeniowej, czy z systemów RFID (identyfikacji osób i przedmiotów na odległość), ERP (planowania zasobów przedsiębior- 
stwa), CRM (wspomagającego pracę działów marketingu, sprzedaży, obsługi klienta, a także zarządu). Wynika to w dużej mierze z niedostatku specjalistów w obszarze technologii informacyjno-komunikacyjnych w FR. Szansą na poprawę w tym zakresie jest projekt „Kadry" w ramach rządowego programu cyfryzacji. Celem projektu jest przygotowanie wykwalifikowanych pracowników na potrzeby gospodarki cyfrowej. Na jego realizację przeznaczono 143,1 mld rubli (ok. 1,9 mld dol.). Istotną rolę odgrywa również poprawa w zakresie dostępu i wykorzystania nowoczesnych technologii, których niedobory w FR występują. Na ten cel, w ramach projektu „Nowoczesne technologie" przeznaczono 451,8 mld rubli [ok. 6,2 mld dol.] (Pravitel'stvo Rossii, 2019, s. 4). Z uwagi na zależność Rosji od zagranicznych dostawców, zwłaszcza sprzętu, cel wdrożenia nowoczesnych technologii będzie bardzo trudny do osiągnięcia w warunkach przyjęcia założenia o opieraniu się wyłącznie na technologii rodzimej produkcji.

- Narastanie zagrożeń technologicznych wiąże się z koniecznością stosowania zabezpieczeń w celu przeciwdziałania spadkowi zaufania społecznego do Internetu i związanego z tym zmniejszenia zainteresowania usługami oraz aplikacjami elektronicznymi, a tym samym obniżaniu ich opłacalności komercyjnej. Bezpieczeństwo procesów tworzenia, przesyłania, przetwarzania oraz przechowywania danych jest coraz istotniejsze dla uczestników procesów gospodarczych i łańcuchów dostaw. Większość przedsiębiorstw w FR korzysta z narzędzi bezpieczeństwa informacji, ale ich wykorzystanie nie jest powszechne wśród obywateli - indywidualnych użytkowników Internetu, czy pracowników organów państwowych i samorządowych. W rządowym programie cyfryzacji na realizację projektu „Bezpieczeństwo informatyczne" przeznaczono 30,2 mld rubli (ok. 412,8 mln dol.) (Pravitel'stvo Rossii, 2019, s. 4).

- Pod względem wykorzystania technologii informacyjno-komunikacyjnych w administracji publicznej, w ostatnich latach Rosja poczyniła duże postępy w realizacji strategii e-administracji (publicznej i samorządów lokalnych). Osoby fizyczne w FR w ograniczonym stopniu korzystają jednak z usług publicznych w formie cyfrowej (np. pobierając formularze urzędowe i wysyłając uzupełnione przez Internet), preferują bezpośrednią obecność w urzędach. W dużych miastach, np. w Moskwie, mieszkańcy chętnie korzystają z serwisów takich jak m.in. system parkowania, opłaty za mieszkania i opłaty komunalne, rejestracja wizyt lekarskich, ale nie jest to powszechne. Sytuacja wy- 
gląda znacznie lepiej w przypadku korzystania z usług e-administracji przez przedsiębiorstwa. Szansą na poprawę w tym zakresie jest projekt „Cyfrowa administracja publiczna” w ramach rządowego programu cyfryzacji. Jego celem jest wdrożenie na szeroką skalę cyfrowych technologii i platform służących przekazywaniu decyzji w administracji publicznej oraz ułatwiających świadczenie usług dla społeczeństwa i biznesu. Na realizację planu przeznaczono 235,7 mld rubli [ok. 3,2 mld dol.] (Pravitel'stvo Rossii, 2019, s. 4).

Poziom rozwoju gospodarki cyfrowej i społeczeństwa cyfrowego w Federacji Rosyjskiej kształtuje się na średnim poziomie w porównaniu do najbardziej konkurencyjnych na świecie gospodarek pod względem cyfryzacji. Wciąż wiele obszarów wymaga poprawy i dalszych działań. Rządowy program cyfryzacji i ujęte w nim projekty mają znaczenie, ale pogorszenie koniunktury gospodarczej w FR wywołanej m.in. przez pandemię Covid-19 oraz wewnętrzne uwarunkowania systemowe nie sprzyjają ich wdrażaniu zgodnie z przyjętymi założeniami i ramami czasowymi (realizację wielu celów w ramach projektów ujętych w programie przesunięto do 2030 r.). Postępy w procesie cyfryzacji FR służące gospodarce i społeczeństwu dostrzegalne będą w perspektywie długookresowej.

\section{Bibliografia}

Administratsiya Prezidenta Rossii (2017), Ukaz Prezidenta Rossiyskoy Federatsii, № 203. O Strategii razvitiyainformatsionnogo obshchestva v Rossiyskoy Federatsii na 2017-2030 gody, www.kremlin.ru, 22.10.2020.

Administratsiya Prezidenta Rossii (2018), Ukaz Prezidenta Rossiyskoy Federatsii, № 204. O natsional'nykh tselyakh $i$ strategicheskikh zadachakhrazvitiya Rossiyskoy Federatsii na period do 2024 goda, www.kremlin.ru, 10.11.2020.

Administratsiya Prezidenta Rossii (2020), Ukaz o Natsional'nykh Tselyakh Razvitiya Rossii do 2030 goda, 21.07, www.kremlin.ru, 12.11.2020.

Andersen B. (2015), Intangible Gold: Why No Rush to Finance Innovation?, w: Sharing in the Success of the Digital Economy. A Progressive Approach to Radical Innovation, red. R. D. Atkinson, M. McTernan, A. Reed, Rowman \& Littlefield International Ltd., London - New York.

Andrews D., Nicoletti G., Timiliotis C. (2018), Digital technology diffusion: A matter of capabilities, incentives or both?, OECD Economics Department Working Papers, no. 1476, OECD Publishing, Paris.

Bechichi N., Grundke R., Jamet S., Squicciarini M. (2018), Moving between jobs: An analysis of occupation distances and skill needs, OECD Science, Technology and Industry Policy Papers, no. 52, OECD Publishing, Paris. 
Brokeš F. (2019), Azjatycki internet z satelity, obserwatorfinansowy.pl, 2.10, https:// www.obserwatorfinansowy.pl/bez-kategorii/rotator/azjatycki-internet-z-satelity, 10.12.2020.

Brooks Ch. J., Craig Ph., Short D. (2018), Cybersecurity Essentials, John Wiley\&Sons, Hoboken, New Jersey.

Brynjolfsson E., McAfee A. (2011), Race Against The Machine: How the Digital Revolution is Accelerating Innovation, Driving Productivity, and Irreversibly Transforming Employment and the Economy, Digital Frontier Press.

Bukht R., Heeks R. (2017), Defining, Conceptualising and Measuring the Digital Economy, Manchester Centre for Development Informatics, Working Paper, no. 68, https://diodeweb.files.wordpress.com/2017/08/diwkppr68-diode.pdf, 4.09.2020.

Check Point Software Technologies (2020), Cyber Security Report, Tel Aviv.

Chernova V. Y., Zobov A. M., Starostin V. S. (2019), Dynamics of Digital Inequality in Russia, „Media Watch”, vol. 10(2).

Davydov S. (2020), Digital literacy: Russia`s path, Riddle Russia, 28.08, https:// www.ridl.io/en/digital-literacy-russia-s-path/, 10.12.2020.

Dimelis S. P., Papaioannou S. K. (2010), FDI and ICT effect on productivity growth, "European Journal of Development Research", no. 22(1).

Dyatlov S. A., Selischeva T. A. (2014), Regionally spatial characteristics and ways to bridge the digital divide in Russia, ,Economics of Education”, vol. 2.

European Commission (2013), Supporting e-governance for citizens and socjety, 18.07, https://cordis.europa.eu/article/id/35899-supporting-egovernance-forcitizens-and-society, 18.12.2020.

Frey C. K., Osborne M. A. (2017), The future of employment: How susceptible are jobs to computerisation?, „Technological Forecasting and Social Change”, vol. 114, Issue C.

Gladkova A., Ragnedda M. (2020), Exploring digital inequalities in Russia: an interregional comparative analysis, „Online Information Review”, vol. 44, Issue 4.

Gokhberg L., Kislyakov E., Kuzminov Y., Sabelnikova M. (eds.) (2020), Digital Economy. Pocked Data Book, National Research University Higher School of Economics, Moscow, https://issek.hse.ru/en/digec2020/, 17.12.2020.

Graham M. (2014), A critical perspective on the potential of the Internet at the margins of the global economy, w: Society and the Internet, red. M. Graham, W. H. Dutton, Oxford University Press, Oxford.

IMD (2020), IMD World Digital Competitiveness Ranking 2020, International Institute for Management Development, IMD World Competitiveness Center, Lausanne - Singapore, https:/www.imd.org/wcc/world-competitivenesscenter-rankings/world-digital-competitiveness-rankings-2020/, 10.12.2020.

IMF (2018), Measuring the Digital Economy, Policy Paper, International Monetary Fund, Washington, 28.02. 
Iordache C., Mariën I., Baelden D. (2017), Developing Digital Skills and Competences: A QuickScan Analysis of 13 Digital Literacy Models, „Italian Journal of Sociology of Education", no. 9(1).

Isin E., Ruppert E. (2015), Being Digital Citizens, Rowman \& Littlefield, London.

Kemp S. (2020), Digital 2020: The Russian Federation, DataReportal, 18.02, https:// datareportal.com/reports/digital-2020-russian-federation, 10.12.2020.

Kevesh M. A., Filatova D. A. (2019), Indeks tsifrovizatsii biznesa, Vysshaya shkola ekonomiki, Institut statisticheskikh issledovaniy i ekonomiki znaniy, Moskva, 27.02, https://issek.hse.ru/data/2019/02/27/1193920132/ NTI_N_121_27022019.pdf, 18.12.2020.

Kuznetsova E., Chernyshova E. (2019), Sberbank perevedet servisy Moskvy na svoyu IT-infrastrukturu, RBC, 5.12, https://www.rbc.ru/politics/05/12/2019/5de908 c19a79470fe2c8829f, 21.12.2020.

Levada-Tsentr (2019), Chetvert' rossiyan poteryali doveriye $k$ televideniyu za desyat' let, 1.08., https://www.levada.ru/2019/08/01/chetvert-rossiyan-poteryali-doverie-k-televideniyu-za-desyat-let/, 16.12.2020.

Manyika J., Roxburgh C. (2011), The Great Transformer: The Impact of the Internet on Economic Growth and Prosperity, McKinsey Global Institute, New York.

Mereminskaya E., Yastrebova C. (2019), Schetnaya palata pokazala, kak zarabatyvayet na goszakupkakh struktura «Rostekha», „Vedomosti”, 28.04, https:// www.vedomosti.ru/economics/articles/2019/04/28/800414-schetnaya-palata-goszakupkah, 23.12.2020.

Meshcheryakov B. (2015), Sberbank kupil kompaniyu u osnovatelya Abbyy, CNews, 12.03, https:/www.cnews.ru/news/top/sberbank_kupil_kompaniyu_u_osnovatelya_abbyy, 21.12.2020.

Meyer S. (2018), The Impact of Digital Life on Society, GRIN Verlag, Munich.

Morandini M. Ch., Thum-Thysen A., Vandeplas A. (2020), Facing the Digital Transformation: are Digital Skills Enough?, European Economy. Economic Brief 054, European Commission, Directorate - General for Economic and Financial Affairs, Publications Office of the European Union, Luxembourg.

Mühleisen M. (2018), The Long and Short of The Digital Revolution, „Finance\&Development”, vol. 55, no. 2.

OECD (2008), The Seoul Declaration for the Future of the Internet Economy, Ministerial session, 18.06.

Paralič J., Sinčák P., Hartono P., Marik V. (red.) (2020), Towards Digital Intelligence Society: A Knowledge-based Approach, Springer, New York.

Peitz M., Waldfogel J. (2012), The Oxford Handbook of the Digital Economy, Oxford University Press, Oxford.

Pieriegud J. (2016), Cyfryzacja gospodarki i społeczeństwa - wymiar globalny, europejski i krajowy, w: Cyfryzacja gospodarki i społeczeństwa. Szanse $i$ wyzwania dla sektorów infrastrukturalnych, red. J. Gajewski, W. Paprocki, 
J. Pieriegud, Instytut Badań nad Gospodarką Rynkową - Gdańska Akademia Bankowa, Gdańsk.

Pravitel'stvo Rossii (2017), Programma „, Tsifrovaya Ekonomika Rossiyskoy Federatsii”, 28.07, http://docs.cntd.ru/document/436754837, 25.10.2020.

Pravitel'stvo Rossii (2019), Natsional'nyye proyekty: tselevyye pokazateli i osnovnyye Rezul'taty, 7.02 .

RAEK (2018), Ekonomika Runeta 2018/Tsifrovaya ekonomika Rossii 2018, Rossiyskaya Assotsiatsiya Elektronnykh Kommunikatsiy, 28.03, https://raec.ru/live/ raec-news/10946/.

RAEK (2020), Runet Segodnya. Glavnyy Analiticheskiy Doklad, Rossiyskaya Assotsiatsiya Elektronnykh Kommunikatsiy, 5.04, https://9fe17689-0acf-41069473-979b3e1cf8ab.filesusr.com/ugd/48c992_95cd43e65a1a418e9fddf5a18cea70e2.pdf, 14.12.2020.

Ragnedda M. (2017), The Third Digital Divide. A Weberian Approach to Digital Inequalities, Routledge, Oxford.

Reisdorf B., Rhinesmith C. (2020), Digital Inclusion as a Core Component of Social Inclusion, „Social Inclusion”, nr 8 (2).

Rykov Y., Nagornyy O., Koltsova O. (2017), Digital Inequality in Russia Through the Use of a Social Network Site: A Cross-Regional Comparison, w: Digital Transformation and Global Society, red. D. Alexandrov, A. Boukhanovsky, A. Chugunov, Y. Kabanov, O. Koltsova, DTGS 2017. Communications in Computer and Information Science 745, Springer, Cham.

Sassi S., Goaied M. (2013), Financial development, ICT diffusion and economic growth, "Telecommunications Policy", no. 37.

Schaub G. (2018), Understanding Cybersecurity, Rowman \& Littlefield, London.

United Nations (2020), United Nations E-government Survey 2020. Digital government in the decade of action for sustainable development, Department of Economic and Social Affairs, New York, https://publicadministration.un.org/ egovkb/Portals/egovkb/Documents/un/2020-Survey/2020\%20UN\%20EGovernment\%20Survey\%20(Full\%20Report).pdf, 19.12.2020.

Van Ark B. (2018), The productivity challenge: jobs and incomes in the dawning era of intelligent robots, Intervention at the Annual Research Conference 2018, European Commission, Directorate-General Economic and Financial Affairs, 19th November.

Vu K. M. (2011), ICT as a source of economic growth in the information age, "Telecommunications Policy", no. 35.

World Bank (2016), Digital Government 2020: Prospects for Russia, World Bank Group, Institute of the Information Society, Washington DC, April, https:// openknowledge.worldbank.org/handle/10986/24402, 15.12.2020.

World Bank (2016), Digital Government 2020: Prospects for Russia, World Bank Group, Institute of the Information Society, Washington DC, April, https:// openknowledge.worldbank.org/handle/10986/24402, 20.12.2020. 
Yarova M. (2019), Countries with the cheapest and fastest Internet: price comparison, ain.ua, 12.12, https://ain.ua/en/2019/12/12/internet-price-comparison-2019/, 10.12.2020.

Yates S., Rice R. E. (2020), The Oxford Handbook of Digital Technology and Society, Oxford University Press, Oxford.

\title{
The level of development of the digital economy and the digital society in the Russian Federation - the main trends and challenges
}

\begin{abstract}
Summary
The aim of the article is to assess the level of development of the digital economy and the digital society in the Russian Federation, as well as identify the main trends and challenges. The analysis has shown that the level of development of the digital economy and the digital society in the Russian Federation is at an average level compared to the world's most competitive economies in terms of digitization. Despite progress in the development of the digital economy and the digital socjety in the Russian Federation under the digitization program, there are still many areas for improvement and further action. The government's digitalization program and the projects it contains are important, but the economic downturn in the Russian Federation, caused by, among other things, the Covid-19 pandemic, and internal system conditions are not conducive to their implementation in accordance with accepted assumptions and timeframes (many of the objectives of the projects included in the program have been put forward to 2030). Progress in the digitalization of the Russian Federation for the economy and society will be visible in the long term.
\end{abstract}

Key words: digital economy, digital society, information and communication technology, Russian Federation

Data przekazania tekstu: 31.12.2020; data zaakceptowania tekstu: 04.03.2021. 